\title{
INTERNATIONAL AND DOMESTIC TRADE REGULATIONS TO SECURE THE FOOD SUPPLY
}

\author{
Christine Kaufmann and Caroline EhLert ${ }^{*}$
}

\begin{abstract}
In a time of global warming, of financial crisis, and of a crisis in food availability we need to ask how the food supply can be secured into the future. The present article considers the extent to which food security is at risk and considers how this risk is currently addressed through international and domestic trade regulation. It gives particular attention to the problems of the poor in the face of increasing biofuel production. It argues that sustainable results can only come about if the interests of the most vulnerable groups of the community are addressed at the international level. In particular, the current regulatory frameworks need to be enforced in order to ensure the food security of the world's population.
\end{abstract}

\section{INTRODUCTION}

During the writing of this article, the number of people suffering from chronic hunger steadily increased to reach an estimated total of 1020 million in 2009. As a result, for the first time in human history, more than one billion people are undernourished. Still, the final declaration of the recent World Food Summit in November 2009 does not promote any new ways to end hunger. ${ }^{1}$ At the same time, glaciers are melting away and temperatures rising at an unprecedented speed, resulting in 5 per cent of the world's population losing their homes because of flooding. The estimated costs of global warming may, according to the Stern Report in 2006, reach 20 per cent of GDP, depending

\footnotetext{
* Christine Kaufmann is Professor of International and Public Law and President of the Board of the Competence Centre for Human Rights at the University of Zurich. Caroline Ehlert is a research fellow at the University of Zurich.

${ }^{1}$ Food and Agriculture Organisation of the United Nations (FAO), 'More People Than Ever are Victims of Hunger' (background note to press release, 19 June 2009) 1 $<$ http://www.fao.org/fileadmin/user_upload/newsroom/docs/Press\%20release\%20juneen.pdf $>$ at 23 June 2009; FAO, Declaration of the World Food Summit on Food Security, WSFS 2009/2, 16-18 November 2009.
} 
on how long the world continues to hesitate to take action. ${ }^{2}$ Nevertheless, it seems that, with the development of the financial crisis, the world has, after a brief period of shock, become used to such large numbers. Millions have been replaced by billions and aid packages for businesses affected by the financial crisis have meanwhile reached astronomical proportions. And yet, at a point in history where climate change, a food crisis and a financial crisis are about to add up to a major human crisis, the fundamental question remains of how food supply can be secured and what role international trade law can play in this regard.

\section{SECURITY OF FoOd SUPPLy IN THE CURRENT FoOd CRISES}

\section{A The Facts}

From 2007 to June 2008, the Food and Agriculture Organisation (FAO) average food price index rose by 53 per cent. There are several reasons for high food prices: weather conditions, international stock levels, increased global food demand, higher oil prices, the biofuel factor, tariffs and policies, developments in financial markets and the weakness of the US dollar. ${ }^{3}$

After record levels of food prices in summer 2008, there has recently been a sharp fall. ${ }^{4}$ Still, in contrast to global food prices which have moderated in recent months, domestic prices remain much higher than in previous years and show few signs of abating. ${ }^{5}$ It is therefore obvious that the recent decline in global prices must not be misinterpreted as the solution to hunger and poverty. In addition, new production statistics reveal that producers in developing countries did not participate in the gains from higher prices, since their supply response was small in 2007 and virtually zero in $2008 .^{6}$ Given that food accounts for a major part of household expenditure for the poor, food prices directly affect their food security.

${ }^{2}$ Lord Todd Stern et al, Stern Review: The Economics of Climate Change (October 2006) $<$ http://www.hm-treasury.gov.uk/stern_review_report.htm> at 17 April 2009.

${ }^{3}$ See Alessandro Flammini, Biofuels and the Underlying Causes of High Food Prices (October 2008) <http://www.fao.org/bioenergy/48659/en/> at 17 April 2009.

${ }^{4}$ See FAO, Food Price Index (2009) <http://www.fao.org/worldfoodsituation/FoodPricesIndex /en/> at 17 April 2009.

${ }^{5}$ The World Bank, Rising Food and Fuel Prices: Addressing the Risks to Future Generations (2008) 2 <http://siteresources.worldbank.org/DEVCOMMEXT/Resources/Food-Fuel.pdf $>$ at 17 April 2009.

6 FAO, Food Outlook, Global Market Analysis (November 2008) 61 <ftp://ftp. fao.org/docrep/fao/011/ai474e/ai474e00.pdf> at 17 April 2009. 
Any discussion about a food crisis inevitably raises the issue of food aid. Statistics show that food aid is not only declining but is also unrelated to food crises. Instead, there is a correlation between low food prices and surplus production on the one hand, and food aid on the other. According to the United Nations World Food Programme, global food aid deliveries declined by 15 per cent in 2007 to 5.9 million tons, thus reaching their lowest level since $1961 .^{7}$ At the same time food prices were high. Competition therefore is an important issue, and we know that cheap imported food aid may destroy local markets to an extent which additionally jeopardises food security.

\section{B Legal Concept of Food Security}

In many parts of the world, agricultural growth will play a key role in addressing the current food crisis. This objective of alleviating food shortages could be achieved by contributing to overall economic growth and by increased joint international efforts to reach the first Millennium Development Goal of halving the proportion of poor and hungry people by $2015 .^{8}$ The Preamble of the Marrakesh Agreement ${ }^{9}$ explicitly addresses 'development' as an overall objective of the World Trade Organisation (WTO) and names international trade as an instrument for achieving this goal. Since food security is an essential part of development, WTO members have obligations concerning food security in their own countries as well as abroad. ${ }^{10}$

'Food security' is a key element in poverty reduction strategies. Besides addressing the availability of food, the concept also covers diverse elements such as people's access to food, the capacity of farmers to survive on what they produce and the ability to comply with cultural food requirements. ${ }^{11}$ At the international level, food security is addressed from the individual's perspective, and includes a right to safe food. ${ }^{12}$ The most widely accepted definition of food security can be found in the 1996 World Food Summit

7 World Food Programme, 2007 Food Aid Flows (June 2008) $1<$ http://www.wfp.org/ interfais/index2.htm> at 14 April 2009.

${ }^{8}$ Shenggen Fan and Mark Rosegrant, 'Investing in Agriculture to Overcome the World Food Crisis and Reduce Poverty and Hunger' (2008) International Food Policy Research Institute Policy Brief 3, $1<\mathrm{http} / /$ www.ifpri.org/sites/default/files/publications/bp003.pdf $>$ at 17 April 2009.

${ }^{9}$ Marrakesh Agreement Establishing the World Trade Organization, opened for signature 15 April 1994, 1867 UNTS 154 (entered into force 1 January 1995) ('Marrakesh Agreement').

${ }^{10}$ Christine Kaufmann and Simone Heri, 'Liberalizing Trade in Agriculture and Food Security - Mission Impossible?' (2007) 40(4) Vanderbilt Journal of Transnational Law 1039, 1056-7.

11 Marsha Echols, Food Safety and the WTO: The Interplay of Culture, Science, and Technology (2001) 17-18, 29-30.

${ }^{12}$ Ibid 27. 
Declaration $^{13}$ and in the World Bank's seminal 1986 Report on World Hunger, which defines food security as a situation in which 'all people, at all times, have physical and economic access to sufficient, safe and nutritious food to meet their dietary needs and food preferences for an active and healthy life. ${ }^{14}$

The legal notion of food security has four aspects, with all of them being subject to a variety of external factors. The first aspect is the availability of food, which is determined by domestic production, import capacity, the existence of food stocks and food aid. The second is access to food, which depends on levels of poverty, the purchasing power of households, prices and the existence of transport and market infrastructure and food distribution systems. The third aspect - stability of supply and access - may be affected by weather, price fluctuations, human-induced disasters and a variety of political and economic factors. The fourth aspect is safe and healthy food utilisation, which depends on care and feeding, food safety and quality, access to clean water, to health care and to sanitation. ${ }^{15}$

This paper will analyse the role of international and domestic regulations in securing food supply. The focus will be on the interface between international law, especially international trade law, and domestic regulation. A brief discussion of the legal framework for trade in agriculture and for food security will be followed by an account of recent developments in this field, including the Doha Round of the WTO. To illustrate the potential impact of domestic policies and their relation to international law, the example of biofuels will be discussed in the fifth Part of this paper. Finally, some options for policymakers to overcome the diagnosed deficits will be suggested in the concluding Part.

\section{FoOd SECURITY IN INTERNATIONAL TRADE LAW}

\section{A Agreement on Agriculture}

The WTO Agreement on Agriculture (AoA) addresses one of the most sensitive areas in international trade law. In industrialised countries,

\footnotetext{
${ }^{13}$ FAO, World Food Summit Plan of Action, 13 November 1996, FAO Doc. W3613/E, [1].

${ }^{14}$ Schlomo Reutlinger et al, Poverty and Hunger: Issues and Options for Food Security in Developing Countries; A World Bank Policy Study (1986) 1.

${ }^{15}$ FAO, The State of Food and Agriculture 2008: Biofuels: Prospects, Risks and Opportunities (2008) 72; The Right to Adequate Food (Art 11): General Comment 12, UN CESCR, 20th sess, UN Doc E/C.12/1999/5 (1999).
} 
agriculture is a generally heavily subsidised industry. Therefore, the AoA attempts to establish 'a fair and market-oriented agricultural trading system' through 'substantial progressive reduction in agricultural support and protection'. ${ }^{16}$ Liberalisation of trade in agriculture is seen as the key instrument in establishing this system. It is built on three pillars which are relevant to food security. ${ }^{17}$

\section{Tariffication}

In line with the general principles of the WTO agreements, existing barriers in domestic law need to be first converted into tariffs (tariffication of non-tariff barriers) and then reduced. ${ }^{18}$ Import protection is thereby limited to tariffs and tariff quotas. This does not, however, automatically imply that import protection is actually reduced. Moreover, in the context of food security it is important to note that the predominant or staple food in the traditional diet of a developing country may be exempted from this obligation. ${ }^{19}$

\section{Domestic Support}

The second pillar of the AoA addresses domestic support. Conceptually, there are two categories of domestic support: support with little or no distorting effect on trade, and trade-distorting support. Support measures which distort are subject to reduction commitments. Nevertheless, article 6 of the AoA exempts a number of measures from the reduction commitments, with the so called 'Green Box' measures being defined in Annex 2 of the AoA. Green Box measures are measures with minimal impact on trade.

The first exemption allows members to provide product-specific support up to a de minimis threshold, which is set at five per cent of agricultural production for developed countries and ten per cent for developing countries.

A second set of exempted measures includes government service programmes which benefit agriculture and the rural community. Such programmes may include programmes of pest and disease control, support for training and information dissemination, and the provision of infrastructure such as drinking water, or of research programmes.

16 Agreement on Agriculture; Marrakesh Agreement Establishing the World Trade Organisation, opened for signature 15 April 1994, 1867 UNTS 410, Annex 1A, Legal Instruments - Results of the Uruguay Round (entered into force 1 January 1995) ('AoA').

${ }^{17}$ Kaufmann and Heri, above n 10, 1043-7; Christine Kaufmann and Mirina Grosz, 'Poverty, Hunger and International Trade: What's Law Got to Do with It? Current Mechanisms and the Doha Development Agenda' (2008) 51 German Yearbook of International Law, 75-109.

${ }^{18}$ AoA, art 4.

${ }^{19}$ AoA, art 5. 
Of immediate relevance for food security is the exemption given to food aid. It includes, for instance, public stockholding for food security purposes, subject to compliance with specific requirements. ${ }^{20}$ Food aid in the form of a domestic food-aid programme for people in need is exempt as well, provided that the government buys products at 'current market prices', and that the financing and administration of the aid is transparent.

Finally, direct payments can become relevant in the food context and be exempted from the reduction commitments. This will occur when they are granted for relief from natural disasters, as structural adjustment assistance, under environmental programmes, or under regional assistance programmes. In order to be exempt such payments must not be linked to current production levels or prices (decoupling).

While the Green Box applies to both developed and developing countries, special treatment is accorded to developing countries with regard to governmental stockholding programmes for food security purposes and subsidised food prices for urban and rural poor. The general criteria for special treatment are that the measures must have no, or at most minimal, trade-distorting effects or effects on production. They must be provided through a publicly-funded government programme not involving transfers from consumers and must not have the effect of providing price support to producers.

\section{Export Competition}

The third pillar of the AoA is the commitment to reduce export subsidies. Given the correlation between production surpluses and food aid this pillar is of particular relevance in tackling the current food crisis.

The AoA limits the use of export subsidies to specific situations mentioned in article 9. Article 9.1 lists the six types of export subsidies that are subject to a reduction commitment. Existing export subsidies must be reduced, and no new export subsidies must be introduced. Developing countries are subject to fewer obligations in this regard, and enjoy longer implementation periods. Least-developed countries are under no obligation to reduce whichever export subsidies they may have.

A number of provisions seek to accommodate what the preamble of the AoA refers to as 'non-trade concerns', among which 'food security' is explicitly mentioned. For example article 12 paragraph 1 of the AoA requires countries

\footnotetext{
${ }^{20}$ AoA, Annex 2, para 3.
} 
to consider food security in importing countries whenever exports are to be reduced or prohibited.

\section{B Marrakesh Decision on Least-Developed and Net- Food Importing Developing Countries}

During the Uruguay Round, negotiators were concerned that the agricultural reform could have negative effects on developing countries by reducing the available supplies of basic foodstuffs from external sources on reasonable terms and conditions, and by creating short-term difficulties in the financing of normal levels of commercial imports. Several analyses had shown that the reform process was likely to increase food import bills as world prices for basic foodstuffs were expected to rise, and that the affected countries could become more dependent on food imports, with food aid declining at the same time. ${ }^{21}$

The response was the Marrakesh Decision on Measures Concerning the Possible Negative Effects of the Reform Programme on Least Developed (LDCs) and Net-Food-Importing Developing Countries (NFIDCs). ${ }^{22}$ The Marrakesh Decision included four response mechanisms: (1) the provision of food aid at an adequate level to meet the needs of developing countries; (2) short-term financing facilities for developing countries in order to allow them to maintain normal levels of commercial imports; (3) favourable terms for agricultural export credits; ${ }^{23}$ and (4) the provision of technical and financial assistance to improve the agricultural productivity and infrastructure of the developing country. ${ }^{24}$

However, this decision has not been satisfactorily implemented. As a result, the Doha WTO Ministerial Conference included the Marrakesh Decision as one of the implementation issues. ${ }^{25}$ From a food security perspective, the

${ }^{21}$ FAO, The Right to Food Guidelines: Information Papers and Case Studies (2006) 66-7 $<\mathrm{http} / / /$ www.fao.org/docs/eims/upload/214344/RtFG_Eng_draft_03.pdf $>$ at 16 April 2009.

${ }^{22}$ Decision on Measures Concerning the Possible Negative Effects of the Reform Programme on Least-Developed and NetFood-Importing Developing Countries; Marrakesh Agreement Establishing the World Trade Organisation, opened for signature 15 April 1994, Decisions adopted by the Trade Negotiations Committee - Results of the Uruguay Round, 1867 UNTS 60 (entered into force 1 January 1995) ('Marrakesh Decision').

${ }^{23}$ This would imply that any agreement relating to agricultural export credits makes appropriate provision for differential treatment in favour of least-developed and net food-importing developing countries.

${ }^{24}$ Ibid arts 3-5.

${ }^{25}$ Ramesh Sharma and Panos Konandreas, 'WTO Provisions in the Context of Responding to Soaring Food Prices, FAO Commodity and Trade Policy Research' (Working Paper No 25, FAO Commodity and Trade Policy Research, 2008) 13. 
Marrakesh Decision is important because of its call for 'a level of food aid commitments sufficient to meet the legitimate needs of developing countries during the reform programme'. ${ }^{26}$ Thereby, the Marrakesh Decision acknowledges that increasing welfare through trade liberalisation is coupled with an increasing legitimate need for assistance of the countries harmed by the process. ${ }^{27}$

\section{Conclusion: Food Security at Risk}

Obviously, the current food crisis has been triggered by various factors. The failure of the AoA is one of them.

A critical evaluation of the AoA shows that one of the key objectives improved market access for developing countries - has not been achieved. With markets in developed countries still being largely closed to products from developing countries, there has been no incentive in these latter countries to substantially increase production. In turn, this initiates a vicious circle of dependence on food imports, with the effect of further weakening domestic production and food security in developing countries.

Second, the AoA did not succeed in sufficiently cutting domestic subsidies. As a result, domestic production in developed countries increased, ${ }^{28}$ with the surplus being sold internationally at prices which producers in developing countries cannot compete with. While the resulting fall in prices seems to be beneficial in the short term, in the long term the competitiveness of farmers in developing countries will be impaired. ${ }^{29}$

With regard to export subsidies, the UN Special Rapporteur on the Right to Food, Olivier de Schutter, rightly diagnosed their detrimental effect on domestic production in developing countries, although their reduction had been praised as one of the major achievements of the Uruguay Round. ${ }^{30}$ Since

\footnotetext{
${ }^{26}$ Marrakesh Decision, Decisions Adopted by the Trade Negotiations Committee - Results of the Uruguay Round, 1867 UNTS 60, para 3 (entered into force 1 January 1995).

${ }^{27}$ Kerstin Mechlem, 'Harmonizing Trade in Agriculture and Human Rights: Options for the Integration of the Right to Food into the Agreement on Agriculture' (2006) 10 Max Planck Yearbook of United Nations Law 127, 160.

28 See Organisation for Economic Co-operation and Development (OECD), Agricultural Policies in OECD Countries: At a Glance (2008).

${ }^{29}$ See M Ataman Aksoy and Aylin Isik-Dikmelik, 'Are Low Food Prices Pro-Poor? Net Food Buyers and Sellers in Low-Income Countries' (Working Paper No 4642, World Bank Policy Research, 2008).

${ }^{30}$ Olivier de Schutter, Promotion and Protection of all Human Rights, Civil, Political, Economic, Social and Cultural Rights, including the Right to Development: Mission to the
} 
the reduction commitments are not combined with obligations to collaborate internationally in preventing price volatility, developing countries are not in a position to effectively compete with developed nations ${ }^{31}$ which again results in negative effects on food security.

Finally, the Marrakesh Decision in theory provides for the measures which, according to experts, might have mitigated the ongoing food crisis, yet they have not been implemented:

\begin{abstract}
Another risk is that the net food buyers are made vulnerable to increases in prices, particularly since many developing States have little of no safety nets to protect the poorest segments of the population from such impacts. The Marrakesh Decision should insure net food-importing developing countries against this risk, but the answer it provides remains partial. For this decision to be fully effective, it would need to include a mechanism to systematically monitor the impact of the AoA reform process on the NFIDCs; it would need to define the notion of 'adequate supplies' of basic foodstuffs (which, under the decision, NFIDCs should be able to obtain from external sources 'on reasonable terms and conditions' throughout the reform process) by reference to the need to ensure that each individual has access at all times to adequate food or to means for its procurement - i.e., that the increased prices which may result from the reform process shall not result in violations of the right to food; and it would need to be fully implemented. ${ }^{32}$
\end{abstract}

The question therefore remains: to what extent can the Doha Round contribute to food security and thereby mitigate the food crisis?

\title{
IV State of Affairs IN THE ONgoing Doha ROUND ${ }^{33}$
}

\section{A The Doha Round as a Development Round}

With the new millennium, global awareness of the alarming dimension of worldwide poverty and food insecurity increased. During the first United Nations Decade for the Eradication of Poverty (1997-2006), the 'Millennium Development Goals and Targets' (MDGs) were declared by the member states of the United Nations (UN). They reaffirm the need for global cooperation to

World Trade Organisation, UN HRC, 10th sess, UN Doc A/HRC/10/5/Add.2 (2009). The Human Rights Council supported de Schutter's conclusions: Resolution 10/12, The Right to Food, 26 March 2009, UN Doc A/HRC/10/L.11, paras 19, 21, 26.

${ }^{31}$ de Schutter, above n 30, para 43.

${ }^{32}$ Ibid para 45.

${ }^{33}$ This Part draws on Kaufmann and Grosz, above n 17. 
deal with the key challenges facing the world. ${ }^{34}$ The first of the MDGs addresses the eradication of extreme poverty and hunger. Its first target is to halve, between 1990 and 2015, the proportion of people whose income is less than US\$1 a day. The second target is to achieve full and productive employment and decent work for all, and the third target is to halve, between 1990 and 2015, the proportion of people who suffer from hunger. The eighth of the MDGs proposes establishing a global partnership for development. It states that, by the year 2015, an open trading and financial system that is rulebased, predictable and non-discriminatory shall have been developed. The needs of LDCs, in particular, shall be addressed.

The MDGs are not legally binding and accordingly have not yet reached the level of priority which they deserve among member states. In addition, the current food crisis puts at risk the small progress already achieved, especially with regard to malnutrition and schooling. ${ }^{35}$ Still, at the policy level, the MDGs serve as a reference for including concrete development goals in several international instruments. This was the case for the Doha Agenda. At the Doha Ministerial Meeting in Qatar on 14 November 2001, a new round of multilateral trade negotiations was launched, with an explicit focus on the development dimension of international trade. ${ }^{36}$

The Ministerial Declaration defines the development agenda of the Doha Round as follows:

2. International trade can play a major role in the promotion of economic development and the alleviation of poverty. We recognize the need for all our peoples to benefit from the increased opportunities and welfare gains that the multilateral trading system generates.

The majority of WTO Members are developing countries. We seek to place their needs and interests at the heart of the Work Programme adopted in this Declaration.

Recalling the Preamble of the Marrakesh Agreement, we shall continue to make positive efforts designed to ensure that developing countries, and especially the least-developed among them, secure a share in the growth of world trade commensurate with the needs of their economic development. In this context, enhanced market access, balanced rules, and well targeted,

\footnotetext{
34 The United Nations Millennium Development Goals originate from the commitments that have been agreed upon with the adoption of the United Nations Millennium Declaration, UN GAOR, 55 ${ }^{\text {th }}$ sess, UN Doc A/Res/55/2 (1998).

${ }^{35}$ The World Bank, above n 5, 2.

${ }^{36}$ Michael J Trebilcock and Robert Howse, The Regulation of International Trade (3rd ed, 2005) 498.
} 
sustainably financed technical assistance and capacity-building programmes have important roles to play. ${ }^{37}$

Acknowledging that market access improvements alone are not sufficient to enhance developing countries' and LDCs' participation in the global trading system, and to eventually lead them out of poverty, the G-8 leaders recognised the need to provide additional Official Development Assistance (ODA) to help enhance trade-capacity with regard to training, institutions and infrastructure. ${ }^{38}$ The WTO Ministerial Conference in Hong Kong approved this initiative by establishing an 'Aid for Trade' package to complement the Doha Development Agenda. ${ }^{39}$ The Hong Kong Declaration called on the WTO Director-General to consult with UN agencies, the World Bank, the International Monetary Fund (IMF), and the regional development banks, to secure additional financial resources.

Not surprisingly, with the ongoing financial and economic crisis, the Aid for Trade programme has not yet accumulated the necessary financial resources. Although, according to the report of the WTO Director-General, Pascal Lamy, Aid for Trade funds increased by US\$4.4 billion to US $\$ 25.4$ in $2007,{ }^{40}$ it is to be expected that any further increase is, if anything, going to be significantly reduced due to the financial crisis. ${ }^{41}$ In addition, structural and institutional deficiencies prevent the Aid for Trade agenda from becoming an efficient instrument to strengthen development countries' trade capacities. ${ }^{42}$

\section{B The July 2008 Package and Beyond}

\section{July 2008 Package}

Negotiations on agriculture were close to an agreement when the Doha Round came to a standstill in July 2008. Since discussions have been resumed, the

\footnotetext{
${ }^{37}$ WTO Ministerial Declaration adopted at the Ministerial Conference on 14 November 2001 in Doha, WTO Doc WT/MIN(01)/DEC/1 paras 2-3.

${ }^{38}$ G8 Gleneagles Summit 2005, The Gleneagles Communiqué, para $22<\mathrm{http} / / / \mathrm{www} . \mathrm{g} 8$. utoronto.ca/summit/2005gleneagles/communique.pdf $>$ at 6 November 2009.

39 World Trade Organisation, Ministerial Conference 2005; Doha Work Programme, Doc WT/MIN(05)/DEC, (adopted 18 December 2005) para 57 (Ministerial Declaration).

${ }^{40}$ WTO, Report to the Trade Policy Review Body from the Director-General on the Financial and Economic Crisis and Trade-Related Developments, (26 March 2009), para 67.

${ }^{41}$ The OECD and WTO will present an updated publication, Aid for Trade at a Glance 2009, at the Second Global Review of Aid for Trade to be held on 6-7 July 2009.

${ }^{42}$ For a detailed discussion see Kaufmann and Grosz, above n 17.
} 
revised draft modalities for agriculture ${ }^{43}$ - the so-called July Package - serve as a basis for further negotiations.

According to the draft, domestic support shall be substantially cut in developed countries. At the same time, the draft provides for less stringent provisions for stockholding related to food security purposes. Income support for farmers is still allowed but needs to be decoupled from production levels, in other words provided in the form of direct payments.

As for market access, tariffs will be cut according to a formula that prescribes higher cuts to higher tariffs. The cutting of tariffs in developing countries will amount to two thirds of that in developed nations. In the food security context it is important that developing countries may also profit from less stringent reductions for special products, that is, products with a crucial importance for a country's development. Moreover, a Special Safeguard Mechanism (SSM), which was designed to protect poor farmers by allowing countries to impose a special tariff on certain agricultural goods in the event of an import surge or price fall, is implemented in the draft.

Finally, all forms of export subsidies in developed countries are to be eliminated by the end of 2013. The draft confirms the members' commitment to maintain an adequate level of food aid by proposing a new article 10.4 on international food aid in the AoA. ${ }^{44}$ For price stabilisation purposes it suggests a new type of intergovernmental commodity agreement. ${ }^{45}$

The July Package leaves many important issues open and addresses others only insufficiently. With regard to market access, all attempts to clearly define the triggers for having recourse to the SSM failed. Similarly incomplete are the suggested provisions on domestic support, which do not adequately address key developments such as trade in biofuels. In addition, the problem of subsidised farmers in developed countries is not solved by limiting support to direct payments. Financial support will still lead to negative impacts on markets for food in developing countries. Furthermore, no progress for food security can be anticipated to flow from the suggested rules and disciplines for export subsidies because, despite the striking lack of correlation between food aid and food crises, no measures have been envisioned to increase the level of food aid to those in need. Finally, the complexity of export restrictions on food is not addressed, although such restrictions have become common in countries where food riots endanger political stability and call for visible

\footnotetext{
${ }^{43}$ WTO Committee on Agriculture - Special Session, WTO Doc TN/AG/W/4/Rev.3 (10 July 2008)(Revised Draft Modalities for Agriculture).

${ }^{44}$ Ibid Annex L para 1.

${ }^{45}$ Ibid para 92.
} 
action. Excluding the issue with reference to the limited mandate of the Doha Round not only seems cynical but, given the long term effects of export restrictions on consumers worldwide, also lacks logic.

\section{Attempts to overcome the deficiencies of the July Package}

A revised draft of the July Package was circulated on 6 December 2008. Its goal was to promote discussion of open issues and of the agenda for future proceedings which were to take place at a Ministerial conference in December 2008. ${ }^{46}$ The draft focused on the emerging consensus regarding the formulation of a general framework and acknowledged the need for further discussion on outstanding issues. Given that cotton had become the "litmus test' of the negotiations, substantial commitments by the European Union and the United States were thought to pave the way for a constructive dialogue with affected countries such as India. Yet, despite these promising developments, not all countries showed the political will to support an agreement. As a result, the Director General of the WTO decided to cancel the Ministerial conference.

Since then, several important political developments have taken place. Elections in India and a new administration in the United States will have an impact on the dynamics of the Doha Round. At the time of writing of this article, a first round of consultations on agriculture had been initiated by the Chair with members and stakeholder groups such as the G-20 in February 2009. The goal was to identify the specific issues which countries are concerned about in order to define the agenda for future discussion and then to revive the traditional format of multilateral - 'Room E' - negotiations. ${ }^{47}$

\section{Further Efforts}

Notwithstanding the slowly moving negotiations in the Doha Round, the discussion on food security and agricultural trade has not come to a standstill.

The 'Cordoba Declaration on the Right to Food and the Governance of the Global Food and Agricultural System' was launched on the occasion of the

${ }^{46}$ WTO Committee on Agriculture - Special Session, WTO Doc TN/AG/W/4/Rev.4, (6 December 2008) (Revised Draft Modalities in Agriculture).

47 WTO, Statement of Chairperson Falconer, 12 February $2009<\mathrm{http} / /$ www. wto.org/audio/2009_02_12_falconer.mp3 $>$ at 19 April 2009. In order to facilitate negotiations, the most controversial issues are being discussed in meetings of 36-37 representative delegations instead of the full membership. Since these meetings take place in Room E at the WTO in Geneva, they are often referred to as Room E negotiations. 
$60^{\text {th }}$ anniversary of the Universal Declaration of Human Rights. ${ }^{48}$ In its preamble the Cordoba Declaration admits 'that conventional approaches to food security have failed'. It suggests that 'food security for all must be considered as a global public good and it must be made a central focus of global governance as well as of national development' ${ }^{49}$ Furthermore, the Cordoba Declaration presents a number of issues and recommendations that should be addressed in further work on chronic hunger and the aggravation of the food crisis. According to the Cordoba Declaration,

States should ... revise policies and practices to guarantee that the food insecure and vulnerable groups in their society can feed themselves directly from productive land or other natural resources, or have the means for the procurement of adequate food. They should also avoid policies and practices that prevent other States from being able to do so.

Moreover it states that

the international community should be ready to provide assistance, when necessary, in order to enable States to meet these priority obligations. Agriculture, food security and the right to food should be given priority in national, regional and international development plans and poverty reduction strategies. ${ }^{50}$

To implement these recommendations the Cordoba Declaration contains suggestions for international cooperation, the promotion of small-scale farming, for reaching coherence with human rights and for the realisation of the right to food. ${ }^{51}$ Overall, the Cordoba Declaration demonstrates how a human rights-based approach to food can offer strategies to address the structural causes of hunger and contribute to food security for all.

UN agencies responsible for dealing with the problem of high food prices met in Madrid in January 2009. The purpose was to accelerate the progress toward the first MDG and to address the effects of price fluctuations on vulnerable populations. ${ }^{52}$ Participants were deeply concerned 'by the negative impact on food access and availability fluctuations exacerbated by the current financial

\footnotetext{
${ }^{48}$ FAO, The Cordoba Declaration on the Right to Food and the Governance of the Global Food and Agricultural System, 10 December $2008<$ http://www.fao.org/righttofood/ download_2008/cordoba_declaration_final.doc> at 17 April 2009 ('Cordoba Declaration').

${ }^{49}$ Ibid Preamble.

${ }^{50}$ Ibid 4.

${ }^{51}$ Ibid 4-6.

${ }^{52}$ Statement of the Madrid High-level Meeting on Food Security for All (27 January 2009) $<$ http://www.ransa2009.org/html/docs/docs/statement_eng_ransa2009.pdf > at 17 April 2009 ('Madrid Statement').
} 
crisis on the livelihoods of the poorest, most vulnerable in the world ${ }^{53}$ Participants were determined to ensure access to adequate food for all in a sustainable manner, to improve nutrition, to stimulate food production, to strengthen social protection systems, and to increase investment in all areas related to food security. ${ }^{54}$ This is intended to be achieved by actions in line with the Comprehensive Framework for Action (CFA). ${ }^{55}$

The CFA was generated by the High Level Task Force on the Global Food Crisis in July 2008. It contains suggestions for enabling the poor and vulnerable groups to deal with the current food crisis and for longer term resilience-building. ${ }^{56}$ To meet the immediate needs of vulnerable populations, the CFA proposes four key policies: First of all, emergency food assistance, nutrition interventions and safety nets are to be enhanced and made more accessible. Second, smallholder farmer food production is to be boosted and trade and tax policies are to be adjusted. Furthermore, macroeconomic implications are to be managed. To build resilience and contribute to global food and nutrition security in the longer-term, additional critical policies have been put forward: The social protection systems are to be expanded and the pace of increasing food availability for smallholder farmers is to be sustained. Finally, access of developing countries to international food markets is to be improved and an international biofuel agreement is to be developed. ${ }^{57}$

An important step was also announced by the president of the UN General Assembly, Miguel D'Escoto Brockmann, on 18 October 2008. This was the establishment of a commission of experts to review the workings of the global financial system, including those of major bodies such as the World Bank and the IMF, and to suggest steps to be taken by member states to secure a more sustainable and just global economic order.

This Commission of Experts on Reforms of the International Monetary and Financial System is chaired by Joseph Stiglitz. In its 2009 report, the Commission emphasises the importance of improving coherence between policies governing trade and finance. ${ }^{58}$ The focus lies on developing countries

\footnotetext{
${ }^{53}$ Ibid para 3.

${ }^{54}$ Ibid para 12.

${ }^{55}$ Ibid para 5.

${ }^{56}$ See High-Level Task Force on the Global Food Security Crises, Comprehensive Framework for Action (2008) <http://www.un.org/issues/food/taskforce/Documentation/CFA\%20Web. pdf> at 22 April 2009.

${ }^{57}$ Ibid paras 6-7.

${ }^{58}$ Report of the Commission of Experts of the President of the General Assembly on Reforms of the International Monetary and Financial System, 21 September 2009 $<$ http://www.un.org/ga/econcrisissummit/docs/FinalReport_CoE.pdf $>$ at 20 November 2009.
} 
with their need for policy frameworks to protect them from regulatory and macro-economic failures in systemically significant countries. ${ }^{59}$ Furthermore, the Commission points out the danger of protectionism which can significantly distort open and fair trade. ${ }^{60}$ According to the Commission, 'there are ... a number of measures that have already been agreed in multilateral trade negotiations which could be implemented rapidly to support developing countries impacted by the crises'. Above all, the Commission claims that the agreement reached at the WTO Ministerial Conference in Hong Kong concerning the elimination of all forms of developed country export subsidies by 2013 should be implemented immediately. In addition, binding commitments on special and differential treatment for developing countries need to be included in the package. ${ }^{61}$ To sum up, the Commission calls for a 'true development round'. This development round should create a legal framework for international trade which strictly promotes agricultural and economic growth in developing countries. ${ }^{62}$

In sum, food security and international trade remain issues of concern for the international community, regardless of the outcome of the Doha Round.

\section{Food SECURITY AND Domestic LAW: THE EXAMPLE OF BIOFUELS}

When it comes to existing domestic regulations on food security, there are essentially four sets of policies: export subsidies, price support, export restrictions and reduced taxes and tariffs on food. A look at recent data shows that export restrictions and food subsidies have increased substantially in the months to April $2009 .{ }^{63}$ In order to illustrate the complex relationship between different sets of norms and interests, the example of subsidies for biofuels will be briefly discussed below.

\section{A Biofuels, the Future of Agriculture?}

As a response to rising oil prices and the lack of alternative fuels for transport, Brazil, the European Union, the United States and several other countries are actively supporting the production of liquid biofuels. The most important biofuels today are ethanol and biodiesel. Ethanol is produced primarily from

\footnotetext{
${ }^{59}$ Ibid paras 29, 57

${ }^{60}$ Ibid para 32.

${ }^{61}$ Ibid paras 109-10.

${ }^{62}$ Ibid paras 85-7.

${ }^{63}$ FAO, above n 15, 110.
} 
sugar cane and maize and, to a far lesser degree, from wheat, sugar beet and cassava. For the production of biodiesel mostly rapeseed, but also palm oil, soybean oil and jatropha is used. The global ethanol production is dominated by sugar cane from Brazil and maize from the United States, China, the European Union and India are other significant ethanol producers. In energy terms, ethanol accounts for almost 90 per cent of the current total global biofuel use. Biodiesel, mostly produced and used in the European Union (predominantly from rapeseed) and increasingly in Southeast Asia (from oil palm), provides the remaining share. Ethanol has represented about 10 per cent of world consumption in recent years, with Brazil being the main exporter. The most important consumer markets are the United States and the European Union. ${ }^{64}$ Obviously, least-developed countries are not yet involved in the production of biofuels.

In 2007, around 23 per cent of US maize production and 54 per cent of Brazil's sugar cane production was used to produce ethanol. In the European Union, about 47 per cent of vegetable oil production was used in the production of biodiesel, necessitating higher imports of vegetable oil in order to meet domestic consumption needs. In energy equivalence, the ethanol share of the gasoline transport fuel market in these countries is estimated at 4.5 per cent for the United States, 40 per cent for Brazil and 2.2 per cent for the European Union. The biodiesel share of the diesel transport fuel market is estimated at 0.5 per cent for the United States, 1.1 per cent for Brazil and 3.0 percent for the European Union. According to the International Energy Agency, there seems to be an upward trend in biofuel usage. Biofuels are predicted to meet 2.3 per cent of world road-transport fuel demand by 2015 and 3.2 per cent by $2030 .^{65}$ Such developments open new perspectives for agriculture, and, not surprisingly, it has been argued that the future of agriculture lies in the production of crops for biofuels. As a result, it is essential to analyse the impact of the production of biofuels on food security.

\section{B The Impacts of Biofuels on Food Security}

Although expanding demand for biofuels is only one of many factors underlying the recent food price increase, ${ }^{66}$ the rapid growth in biofuel

\footnotetext{
${ }^{64}$ FAO, 'High-level Conference on World Food Security: The Challenges of Climate Change and Bioenergy, Bioenergy, Food Security and Sustainability - Towards an International Framework' (Paper presented at the High Level Conference on World Food Security, Rome, 3-5 June 2008) 1-2<http://www.fao.org/bioenergy/48659/en/> at 17 April 2009.

${ }^{65}$ Ibid 2-3.

${ }^{66}$ The World Bank, Rising Food Prices: Policy Options and World Bank Response (April 2008) 1-2 <http://siteresources.worldbank.org/NEWS/Resources/risingfoodprices_ backgroundnote_apr08.pdf $>$ at 17 April 2009.
} 
production will affect food security at the national and household levels mainly through its impact on food prices and incomes. In terms of the four aspects of food security (availability of food, access to food, stability of supply and access, and safe and healthy food utilisation), the discussion focuses on the impacts of higher food prices on availability and access at the national level, as well as at the household level. In the medium to longer term, higher agricultural prices offer the potential for a supply response by setting incentives to increase production and for strengthening and revitalising the role of agriculture as an engine of growth in developing countries. ${ }^{67}$

\section{$1 \quad$ National Level}

At the national level, a criterion for food security is the availability of food. How individual countries will be affected by higher prices will depend on whether they are net agricultural commodity importers or net exporters. While some countries will profit from higher prices, the Net-Food-Importing Developing Countries are expected to be significantly worse off as they depend on imports due to the deficit in agricultural trade that they have experienced over the last 20 years. ${ }^{68}$ For these low-income countries in particular, the higher import prices will significantly increase food import bills, since food imports are predicted to more than double between 2000 and $2030 .{ }^{69}$

\section{$2 \quad$ Household Level}

Even if biofuels are only one of the several sources of recent increases in food prices, expanded biofuel production will still continue to exert upward pressure, especially on domestic food prices, for a considerable time to come. In the short run, these higher agricultural commodity prices will have widespread negative effects on household food security. Particularly at risk are poor urban consumers and poor net food buyers in rural areas, who tend also to be the majority of the rural poor. Their incomes, which are on average significantly lower than those of the urban populations, are insufficient to buy the food which they do not produce themselves. ${ }^{70}$

\footnotetext{
${ }^{67}$ FAO, The State of Food Insecurity in the World 2008: High Food Prices and Food Security - Threats and Opportunities (2008) 34, 38 <http://www.fao.org/docrep/011/i0291e/i0291e00. htm> at 17 April 2009.

${ }^{68} \mathrm{FAO}$, above $\mathrm{n} 15,73$ (figure 27 ).

${ }^{69}$ de Schutter, above n 30, 4.

${ }^{70}$ The World Bank, World Development Report 2008 - Agriculture for Development (2007) 109 (figure 4.7).
} 
There is a strong need to establish appropriately designed and targeted safety nets to ensure access to food by poor and vulnerable groups. Options include special cash transfers to the poor and vulnerable populations which support their purchasing power without altering domestic incentives to produce more food. With this approach, transfers are not reducing the incomes of poor food sellers. ${ }^{71}$ Examples of cash or near-cash transfers are, in the majority of cases, linked to specific requirements with regard to income, location, occupation or sending children to school. A role model for such systems is the 'Bolsa Família Program', which is supported by the World Bank and cited as one of the key factors behind the positive social outcomes achieved by Brazil in recent years. ${ }^{72}$ However, in low-income countries with weak administrative capacities cash transfers may not be feasible. ${ }^{73}$

Another possible means of ensuring household food security is the lowering of domestic food prices. Measures to lower domestic prices include reducing tariffs and other taxes on key staple foods. Many countries impose tariffs on food imports to encourage domestic production and increase domestic income. When food prices are high, reductions in tariffs and taxes can provide some relief to consumers, yet at a fiscal cost. The income loss from reducing tariffs can be significant, and the fiscal implications of a combination of tariff reduction with additional social protection expenditures may require cutbacks in other areas. ${ }^{74}$

Other countries continue to maintain high tariffs to protect domestic producers. However, such high tariffs negatively affect the large majority of the poor, who are net consumers. To cope with the resulting household food insecurity, several countries have a long history of using bread or grain subsidies specifically targeted to poor and vulnerable groups.

A further option is the introduction of consumer subsidies for staple foods. The risk with such measures is that they can generate high fiscal costs. Moreover, if consumer subsidies are met by measures to keep producer prices low, the result may be a disincentive for domestic food producers. The only exception is when price controls are explicitly introduced as a temporary measure and are widely felt to be justifiable in terms of a higher social goal.

\footnotetext{
${ }^{71}$ The World Bank, above n 66, 3-4.

${ }^{72}$ Poor families with children receive an average of $\mathrm{R} \$ 70.00$ (about US\$35) in direct transfers. In return, they commit to keeping their children in school and taking them for regular health checks: The World Bank, Bolsa Familia; Changing the Lives of Millions in Brazil (2009) $<$ http://go.worldbank.org/M4EQDZNQX0> at 17 April 2009.

${ }^{73}$ The World Bank, above n 66, 3.

${ }^{74}$ Ibid 4 (figure 2).
} 
In such cases, the risks of an aggravation of food insecurity will be minimised. $^{75}$

In sum, while there are many options to protect the poor and vulnerable populations, there is no 'one size fits all' solution. Instead, governments in affected countries need to tailor specific programmes according to the need of their populations.

\section{Biofuels Crop Production as a Trigger for Agricultural Growth}

In the longer run, growing demand for biofuels and the resulting rise in agricultural commodity prices can present an opportunity to promote agricultural growth and rural development in developing countries, with potentially positive implications for economic growth, poverty reduction and food security. Many of the world's poorest countries are agro-ecologically well placed to become major producers of biofuels. The most promising regions for the production of biofuels are Sub-Saharan Africa, East Asia, Latin America and the Caribbean. ${ }^{76}$ However, it requires strong government commitment to enhance agricultural productivity, for which public as well as private investments in infrastructure, institutions and technology, among other factors, are crucial. The FAO has tabled an investment road map to 2015 and assessed its potential benefits. This assessment suggests that a total annual investment volume of US $\$ 30$ billion in these areas would create an overall annual benefit of US $\$ 120$ billion. $^{77}$ Other studies have shown that a onehectare farm requires an investment volume of about US\$200 to produce an additional food yield of one to two tons with a market value of approximately US $\$ 450 .^{78}$

Supportive policies must focus above all on enabling poor small producers to expand their production and gain access to markets. Involving these smallholder farmers in biofuel feedstock production is important for reasons of equity and employment. In order to promote smallholder farmers, governmental policy intervention is required, especially in the form of sponsorship for innovative approaches to rural finance and through the enforcement of contracts. A noteworthy example is the 'Social Full Stamp'

\footnotetext{
${ }^{75}$ Ibid 4-5.

${ }^{76}$ Richard Doornbosch and Ronald Steenblik, 'Biofuels: Is the Cure Worse than the Disease?' (Paper presented at the OECD Round Table on Sustainable Development, Paris, 11-12 September 2007)[19] <http://www.oecd.org/dataoecd/15/46/39348696.pdf> at 23 April 2009.

${ }^{77}$ FAO, above n 6, 62 .

${ }^{78}$ Jeffrey Sachs, Common Wealth-Economics for a Crowded Planet (2008) 231.
} 
programme created by Brazil's government to encourage biofuel producers to purchase feedstock from small family farms. It promotes the inclusion of smallholder farmers in the biofuel production chain, generating employment and higher income for this social group. ${ }^{79}$ The participation of smallholder farmers in the form of contract farming seems to be the most effective approach to building the necessary market while safeguarding staple food production and ensuring agricultural growth. However, its success will depend on the existence of an enabling policy and legal framework. ${ }^{80}$

Opportunities for developing countries would expand with the removal of subsidies and trade barriers that support producers in the member countries of the Organisation for Economic Co-operation and Development (OECD) at the expense of producers in developing countries. Biofuel development in OECD countries has been promoted and supported by governments through a wide range of policy instruments. Such instruments include subsidies and tax incentives. Several countries are subsidising investments in infrastructure and transportation. Tariff barriers for biofuels are also widely used by the major ethanol producers to protect domestic agriculture and biofuel industries, to support domestic prices of biofuels and to provide an incentive for domestic production. ${ }^{81}$ According to the FAO, the removal of these tariffs and subsidies would induce a decline in global ethanol production and consumption of about $10-15$ per cent. This would lead to a significant increase in imports in currently protected markets, while production and exports from developingcountry suppliers would be boosted. ${ }^{82}$

\section{Assessment}

The introduction of biofuel production to developing countries brings not only opportunities but also risks. This is why a more consistent set of policies and a better legal framework for the production of biofuels is needed. Biofuel policies must be protective of poor and vulnerable populations. At the same time, they should enable agricultural growth, both by improving economic and technical efficiency and by ensuring that developing countries can participate in future market opportunities. Furthermore, they need to be outward-looking and market-oriented so as to reduce existing distortions in biofuel and agricultural markets and avoid introducing new ones.

\footnotetext{
79 FAO, Opportunities and Challenges of Biofuel Production for Food Security and the Environment in Latin America and the Caribbean (April 2008) [14] $<$ http://www.fao.org/bioenergy/48659/en/> at 17 April 2009.

${ }^{80} \mathrm{FAO}$, above n $15,81-2$.

${ }^{81}$ Ibid $27-8$

${ }^{82}$ Ibid 50-1.
} 
Biofuel feedstock production would lead to an introduction of cash crops to the rural regions in developing countries. This may encourage private investment in infrastructure, institutions and technology, from which eventually also food crop production and other farm activities could benefit. Where farmers have access to bank credits, investments and equipment, they are able not only to boost their incomes but also to intensify food production on their lands. ${ }^{83}$ This would lead to an increase in employment. In terms of the employment effects of the production of biofuels, Brazil is a good example. The biofuel sector created about one million jobs in 2001. These jobs were in rural areas and mostly for unskilled labour. The indirect creation of employment in manufacturing and other sectors was estimated to amount to another 300000 jobs. $^{84}$

Needless to say, the expansion of biofuel production will lead to greater competition for land. As a result, female farmers (and other smallholder farmers) who mostly have weak land-tenure rights, may be excluded from biofuel production and even be displaced. In most developing countries, there are significant gender gaps in land-tenure rights. For instance in Cameroon, women undertake 75 per cent of the agricultural work but they own only 10 per cent of the land. Additionally, the chance for women to receive bank loans, which is essential for increasing productivity and adapting to change, is significantly low in most developing countries. Therefore, many women do not have the opportunity to participate in the production of biofuels. ${ }^{85}$ Policies and legal frameworks are necessary to enable female farmers to participate in the new markets.

Above all, indigenous communities may be particularly vulnerable. ${ }^{86}$ Often their land rights are not guaranteed by the government as they should be according to the UN Declaration on the Rights of Indigenous Peoples. ${ }^{87}$ An example of forced displacements in the context of biofuel production is the eviction of Afro-Colombians in Colombia. ${ }^{88}$ To prevent smallholder farmers,

\footnotetext{
${ }^{83}$ Ibid $80-2$.

${ }^{84}$ José Roberto Moreira, 'Brazil's Experience with Bioenergy' in Peter Hazell and R Pachauri (eds), International Food Policy Research Institute: Bioenergy and Agriculture, Promises and Challenges, Vision 2020 (December 2008) Focus 14, Brief 8 of 12 $<\mathrm{http} / / /$ www.ifpri.org/sites/default/files/publications/focus14_08.pdf $>$ at 22 April 2009.

${ }^{85}$ Andrea Rossi and Yianna Lambrou, Gender and Equity Issues in Liquid Biofuels Production: Minimizing the Risks to Maximize the Opportunities (2008) 5-6.

${ }^{86}$ FAO, above n $15,83$.

${ }^{87}$ See United Nations Declaration on the Rights of Indigenous Peoples, UN GAOR, 61st sess, art 8.2 (b), UN Doc A/Res/61/295 (2007).

${ }^{88}$ Walter Kälin, Report of the Representative of the Secretary-General on the Human Rights of Internally Displaced Persons, Addendum: Mission to Colombia UNHRC 4th sess, UN Doc A/HRC/4/38/Add.3 (2007), para 19; International Displacement Monitoring Centre,
} 
women and indigenous communities from being displaced, efficient policies and a strong legal framework are required.

\section{CONCLUSION: WHICH WAY FORWARD?}

Food security raises many legal issues. It involves several legal dimensions, both with regard to disciplines and levels of regulation. Thus it involves trade law, agricultural law and human rights law, and it involves law on the domestic and the international level.

To mitigate the short term effects of the current crises on food security, domestic policy is essential. As the example concerning biofuels shows, there is a strong need to establish appropriately designed and targeted safety nets to ensure access to food for poor consumers in urban areas and poor net food buyers in rural areas. It is also crucial to lower domestic food prices or to subsidise the poor - in compliance with international trade law - to cope with household food insecurity. Domestic policy also needs to focus on enabling smallholder farmers to expand their production and gain access to markets in order to participate in the supply response and profit from higher prices.

Sustainable results can only be achieved if the interests of the most vulnerable - the poor, minority groups, women and children - are in the long term addressed at the international level. If trade is to substantially contribute to development and the realisation of food security for all, it needs to allow for more flexibility to developing countries. Above all, the three pillars of the AoA should be enforced, especially in the OECD countries, to give developing countries the opportunity to become fully-fledged participants in the benefits of international trade and agricultural development.

The necessary changes will not happen automatically. Instead, the legal framework needs to be enforced in order to implement food security for all. In the words of Pascal Lamy, Director General of the WTO:

the benefit of trade opening for human rights is not automatic. It presupposes rules that are both global and just. Rules of the kind that prompted Lacordaire to say that 'between the weak and the strong, poor and

Norwegian Refugee Council, Colombia: Rate of New Displacements Highest in Two Decades - A Profile of the Internal Displacement Situation (17 October 2008) 48-53<http://www. reliefweb.int/rw/RWFiles2008.nsf/FilesByRWDocUnidFilename/MCOT-7KHFVVfull_report.pdf/\$File/full_report.pdf $>$ at 25 October 2009; Minority Rights Group International, World Directory of Minorities and Indigenous Peoples - Colombia: Nukak and Tukano (2008) UNHCR Refworld <http://www.unhcr.org/refworld/docid/49749d3a22. html> at 23 April 2009. 
the rich ..., liberty is the oppressor and the law is freedom'. Negotiating and implementing such rules is the WTO's basic mission, and its primary vocation in so doing is to regulate and not to deregulate as is often thought. $^{89}$

${ }^{89}$ Pascal Lamy, 'Globalization and Trade Opening Can Promote Human Rights' (Speech delivered at the occasion of the Dies Academicus Ceremony of Award of a Doctor Honoris Causa, Geneva, 5 June 2009) <http://www.wto.org/english/news_e/sppl_e/sppl128_e.htm> at 7 June 2009. 